\title{
Breast Centers in Germany
}

\author{
Ute-Susann Albert Uwe Wagner Matthias Kalder \\ Department of Gynecology, Gynecological Endocrinology and Oncology, Breast Center Regio, University of Marburg, Germany
}

Key Words

Breast neoplasms - Breast center - Certification . Guidelines - Quality of care

\section{Summary}

A decrease in medical practice variations in national breast cancer care has been shown to improve survival and the negative impact of the disease on affected women and their families. The following report describes the concert of efforts undertaken by the medical societies to optimize national breast cancer care by organizational centralization of multidisciplinary medical competence in certified breast centers ( $C B C$ ), aiming to attain continual quality of health care by implementation of evidenceand consensus-based guidelines. Centralization and the systematic pursuit of organizational development by tracking guideline adherence using performance quality indicators over time demonstrate the feasibility and practicability of the implementation concept to bridge the gap between determined scientific best evidence and applied best practice. However, the proof of concept will remain pending until the data of the population-based cancer registries are analyzed for survival estimates.

\section{Introduction}

Despite medical advances made in the field, breast cancer in women remains a challenging problem of oncologic health and patient care in Germany and throughout the world. The national burden of cancer can be best described by data derived from the population-based cancer registries. Breast cancer is by far the most common cancer of women in Germany, comprising $27.8 \%$ of all female cancers, with 57,230 new cases in the year 2004 (mean age 63 years). The estimated age-adjust-

\section{Schlüsselwörter}

Brustkrebs · Brustzentrum · Zertifizierung · Leitlinien ·

Versorgungsqualität

\section{Zusammenfassung}

Die Egalisierung von Unterschieden in der flächendeckenden Versorgungsqualität stellt eine Möglichkeit dar, Überleben und negative Auswirkungen der Brustkrebserkrankung auf betroffene Frauen und ihre Familien zu verbessern. Die Arbeit beschreibt die gemeinsamen Anstrengungen der Fachgesellschaften, das Ziel einer kontinuierlichen, qualitätsgesicherten Gesundheitsversorgung durch Umsetzung evidenz- und konsensusbasierter Leitlinien mit Hilfe organisatorischer Bündelung multidisziplinärer medizinischer Kompetenz in zertifizierten Brustzentren (CBC) zu erreichen. Zentralisierung und die systematische Nachverfolgung zeitabhängiger Organisationsentwicklung mit Hilfe von Leitlinien-Qualitätsparametern zeigen die Durchführbarkeit und Praktikabilität des Umsetzungskonzeptes, die Vorgaben wissenschaftlich bester Evidenz in angewandte beste Praxis zu überführen. Allerdings bleibt der Nachweis über den Erfolg des Konzeptes bis zum Vorliegen der bevölkerungsbezogenen Krebsregisterdaten zum Überleben offen. ed incidence rate (European standard) is high with 104.2 per 100,000 [1]. The incidence of breast cancer is rising [2], showing a high, albeit declining, mortality rate (26.8 per 100,000 in 2004) [1]. The 2000-2002 period estimates of 10-year relative survival rates of breast cancer in Germany were $69 \%$ showing a moderate improvement of $4 \%$ compared to the data for 1990-1992 [3]. The trends in age-adjusted 5-year relative survival of patients comparing the period of 1990-1994 with the data of 2000-2004 demonstrate an increase of 7.2\% units with 5-year relative survival estimates of $80.4 \%$ [4]. The data

\section{KARGER}

Fax +497614520714

Information@Karger.de

www.karger.com (c) 2009 S. Karger GmbH, Freiburg

Accessible online at:

www.karger.com/brc
PD Dr. med. Ute-Susann Albert

Brustzentrum Regio

Klinik für Gynäkologie, Gynäkologische Endokrinologie und Onkologie

Baldingerstraße, 35043 Marburg, Germany

Tel. +49 6421 58664-32, Fax -07

albertu@med.uni-marburg.de 


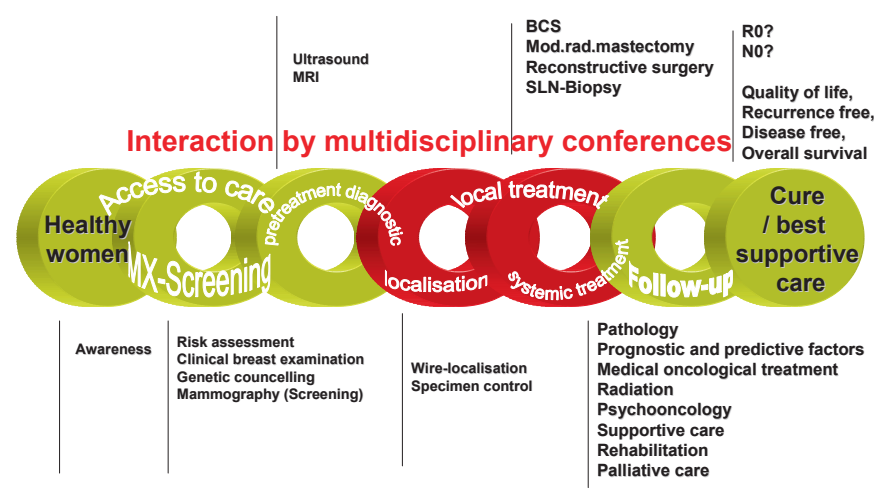

Fig. 1. The chain of breast cancer care.

on metastasized breast cancer demonstrates no improvement in life expectancy in the past 20 years [5]. The moderate improvement in long-term survival rates during the past decade is likely to be due to more effective adjuvant treatment in the absence of an early breast cancer detection program in Germany. The combination of high incidence and relatively good prognosis compared to other cancers make breast cancer the most prevalent cancer. Furthermore, breast cancer has a negative impact on virtually every aspect of the lives of the affected women and their families.

The population-based cohort data collected in 6 regions in Germany between 1996-1998 revealed a great variance in the quality of breast cancer treatment across the country [6]. Potential for improvement was identified for the following aspects: quality of health care across all aspects of the chain of breast cancer care, especially for early detection of breast cancer and adherence to treatment standards; appropriate use of resources within the health care system; clinical data management; establishment of cancer registries [7]. The 2001 health care report of the German government advisory board depicted breast cancer care as one of the primary aims to improve women's health care within the next decade [8]. Thus, in line with the directives of the European Union and the World Health Organization, the development of national cancer guidelines and their implementation are recognized as major tools for improvement $[9,10]$.

Two major steps have been undertaken by the German Cancer Society (Deutsche Krebsgesellschaft, DKG) and the German Society of Senology (Deutsche Gesellschaft für Senologie, DGS) to increase the quality of breast cancer care throughout the country: The development of high-quality guidelines and the establishment of certified breast centers (CBCs).

\section{Guideline Development}

The first evidence- and consensus-based guidelines (S3) for the 'Early detection of breast cancer' [11], [12] and 'Diagno-

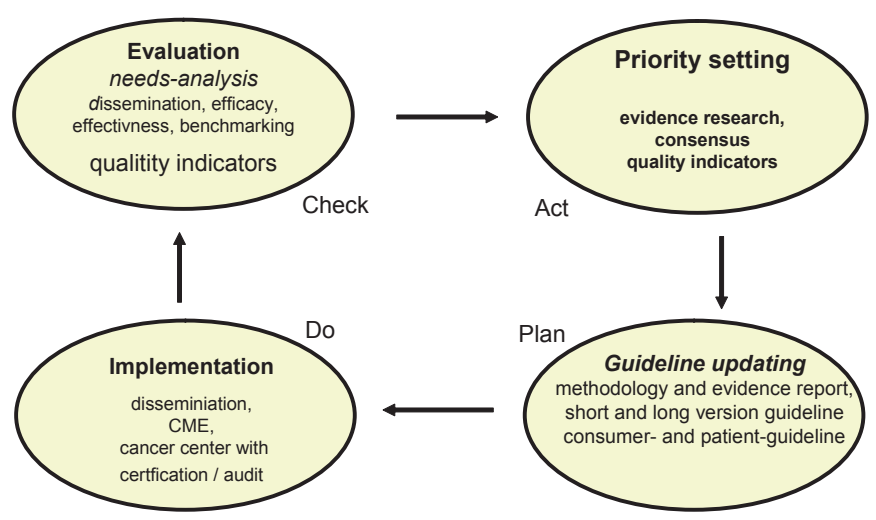

Fig. 2. Quality management cycle of GCP-guidelines.

sis, treatment, and follow-up of women with breast cancer' [13] were developed 2003/2004 according to the criteria established by the Association of the Scientific Medical Societies (AWMF) [14] and the German Agency for Quality in Medicine (Ärztliches Zentrum für Qualität in der Medizin, ÄZQ) with all systematic elements including quality assurance and quality indicators. The (S3) guidelines cover all aspects of the chain of breast cancer care (fig. 1), and the recommendations are in line with the national context. The conceptual framework follows a classical quality management cycle [15] to ensure timely updating, integrating methodological soundness and the impact the guidelines have in terms of dissemination (accessibility) and implementation (acceptance and use) [16] (fig. 2). The guidelines were updated in 2008 [17, 18].

Important for the transfer of the guidelines' content are dissemination and continuous certified education (CME) [19]. Crucial is the establishment of practical use in routine care. Implementation of guidelines in an institution has to consider the regional and local context. Organizational changes have to be made due to evolving knowledge and technology, which necessarily requires quality management to assure practicability, financial resources, and acceptance by physicians and patients. Quality assurance in accordance with the guidelines make the establishment of clinical pathways and documentation systems mandatory. Independent external monitoring is recognized to support continuous organizational improvements, and feedback assists in delivering guideline-based best practice. For comprehensive guideline adaptation, the establishment of breast units or breast centers has been suggested [20].

\section{Certified Breast Centers}

The DKG and DGS are heavily involved in the promotion of high standards of oncological health care services throughout Germany. Such an ambition involves recognition of centers specializing in the management of breast cancer patients. 


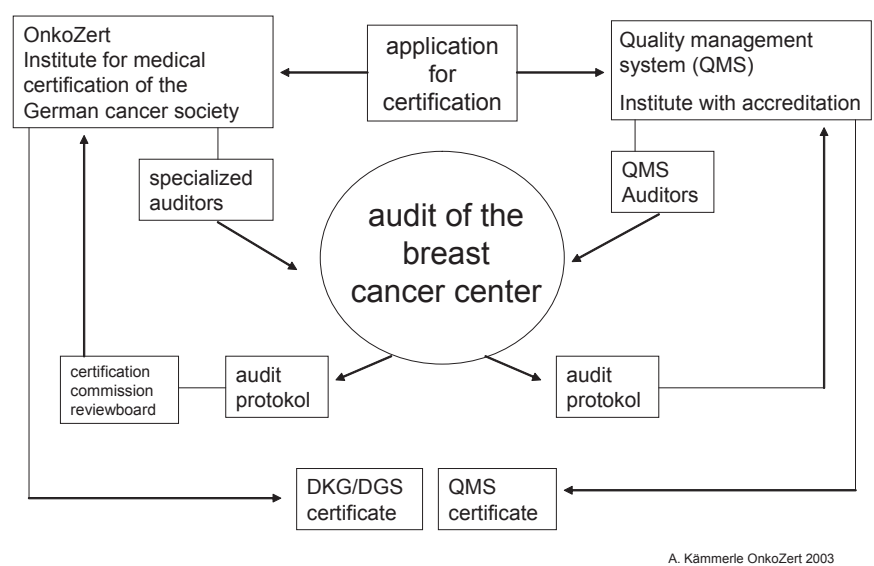

Fig. 3. Certification process.

These centers have a multidisciplinary system to provide total quality management of breast cancer patient care, and are concerned with the delivery of care to the highest available standards. High standards can be ensured if all disciplines involved in breast health care follow established (S3) guidelines and adjust protocols for early detection, diagnosis, treatment, and follow-up care for implementation in independent local and regional practice. Common criteria have been defined by the certification commission of the scientific societies for appropriate work in a multidisciplinary environment, and a system for core requirements, evaluation, and certification has been in place since 2003 (fig. 3). The German S3 guidelines form the basis for the 173 core requirements and quality indicators covering the aspects of breast cancer care depicted in table 1.

Hospitals with breast units interested in qualifying as breast centers apply to OnkoZert, an independent institute for certification. Applications are reviewed for eligibility for the certification process. Once assigned, the audit conducted by certified auditors is performed within a defined time frame. The auditors are experts in the field of breast cancer care, who have passed a special training and achieved accreditation as auditors for CBCs. The formal process is finalized by the certification commission after the audit plan and the audit report are reviewed and approved. CBCs in Germany hold 2 certificates: one of the German scientific societies certified by OnkoZert and one of an internationally accepted quality management system such as ISO 9001:2000 certified by an independent accreditation institute (fig. 3). The objective to combine the certification process is the systematic pursuit of process improvement in order to attain continual quality of health care, the prevention of errors and other adverse outcomes, and the reduction of variations and organizational ineffectiveness and inefficiency. The certification process is run in 3-year cycles starting with the first certification audit, followed by annual follow-up audits for the next 2 years, and starting a new cycle by a re-certification audit.
Table 1. Core requirements for breast centers

\author{
Organizational aspects of the breast center \\ Network of the breast center \\ Conferences and treatment planning \\ Cooperation with ambulatory care physicians \\ Advocacy and self-help groups \\ Psycho-social and -oncological care \\ Patient involvement \\ Clinical study management \\ Nursing \\ Radiology (diagnostic imaging) \\ Nuclear medicine \\ Senology (outpatient clinics, breast surgery, breast reconstruction) \\ Radiation therapy \\ Pathology \\ Medical oncological treatment \\ Supportive and palliative care \\ Tumor documentation/outcome \\ Quality measures
}

\section{Evaluation of Guideline Implementation: Can Practice Variations be Reduced?}

To evaluate the status of implementation and institutional changes, this report concentrates on the impact CBCs might have on reducing medical practice variations. Medical practice variations are defined as variations between units (hospitals, regions, countries), reflecting the decisions made by physicians. Characteristics of the units, not the characteristics of patients, are relevant in this type of study. The theoretical framework by Groenwegen and Westert [21] to explain trends in medical practice variation is used.

To establish a trend in practice variation, reports were made at 5 different points in time during the period of 20032008. The following target measures have been selected: number of established CBCs, rates of guideline adherence exemplary for 6 selected process quality indicators. Published data of the benchmarking study of CBCs [22] and data from the national quality assurance report of breast cancer surgery in Germany [23] have been extracted for a descriptive evaluation of changes over time. No statistical tests were used.

\section{Results and Discussion}

Within a period of 5 years, by introducing CBCs into the German health care system, breast cancer care has changed from a decentralized to a more centralized health care approach. The number of CBCs increased remarkably from 8 (2003) to 181 (2008) with a nationwide distribution. According to the data collected at OnkoZert in the year 2008, $\mathrm{n}=$ 41,322 patients with primary breast cancer were treated in CBCs (table 2). Considering the increasing incidence trend, 
Table 2. Development of certified breast centers (CBCs) in Germany

Table 3. Results of the national quality report for breast cancer surgery (BQS [23])

\begin{tabular}{lllllll}
\hline & 2003 & 2004 & 2005 & 2006 & 2007 & 2008 \\
\hline CBCs, $n$ & 8 & $51^{\mathrm{a}}$ & 99 & 135 & 163 & 181 \\
$\begin{array}{l}\text { Primary breast } \\
\quad \text { cancer cases, } \mathrm{n}\end{array}$ & $1,624^{\mathrm{a}}$ & $10,404^{\mathrm{a}}$ & 20,089 & 27,722 & 33,955 & 41,322 \\
\hline a Data estimated. & & & & & & \\
\hline
\end{tabular}

\begin{tabular}{|c|c|c|c|c|c|}
\hline & 2003 & 2004 & 2005 & 2006 & 2007 \\
\hline $\begin{array}{l}\text { Rate of guideline } \\
\text { adherence, \% }\end{array}$ & 36.02 & 57.43 & 65.01 & 83.9 & 91.2 \\
\hline Range, \% & $34.89-37.16$ & $56.80-58.07$ & $64.37-65.64$ & $83.33-84.48$ & $90.8-91.2$ \\
\hline Cases, $\mathrm{n}$ & 6,996 & 23,340 & 21,905 & 15,829 & 16,609 \\
\hline \multicolumn{6}{|c|}{ Quality indicator for breast surgery: specimen radiography } \\
\hline
\end{tabular}

Pre-operative wire marking and the verification of the correct surgical excision of the lesion should be done in principle in the presence of any non-palpable imaging finding. Level of Evidence 3b, Grade of Recommendation A, Source: Guideline Adaptation [11, 36, 37], A Reference level for guideline adherence: $>95 \%$
Table 4. Benchmarking data from a voluntary network of breast centers ([22])

\begin{tabular}{|c|c|c|c|c|c|c|}
\hline Quality indicator & 2003 & 2004 & 2005 & 2006 & 2007 & $\begin{array}{l}\text { FAB requirements and } \\
\text { reference level for } \\
\text { guideline adherence, \% }\end{array}$ \\
\hline $\begin{array}{l}\text { Preoperative histological } \\
\text { confirmation of diagnosis, \% }\end{array}$ & 58 & 71 & 78 & 84 & 88 & $>90$ \\
\hline Breast conserving surgery for $\mathrm{T} 1, \%$ & no data & no data & 79 & 83 & 85 & $>60$ \\
\hline Appropriate axillary surgery, $\%$ & 85 & 85 & 80 & 83 & 88 & $>90$ \\
\hline Hormone receptor assessment, \% & 92 & 96 & 96 & 97 & 98 & $>95$ \\
\hline $\begin{array}{l}\text { Appropriate endocrine treatment in } \\
\text { hormone receptor-positive cases, \% }\end{array}$ & 27 & 82 & 92 & 94 & 93 & $>90$ \\
\hline
\end{tabular}

we estimate that more than $60 \%$ of all primary breast cancer patients are treated in CBCs. The structural changes observed on a national level are in line with published data of hospital volume activity from the regional level of the federal state of Hessen. In the year 2001, $\mathrm{n}=84$ hospitals were involved in the regional care of breast cancer patients. $70 \%(n=59)$ of the hospitals performed breast surgery in less than 50 primary breast cancer cases, $20 \%(\mathrm{n}=18)$ between 50 and 150 , and $8 \%(n=7)$ over 150 . Looking at the patient distribution data of 2001 , only $38 \%(n=1416)$ of all breast cancer patients were treated in hospitals with more than 150 primary breast cancer cases [24]. By now, 15 hospitals in the county have been certified as breast centers either according to DKG/DGS or with the accreditation of EUSOMA [25], meeting the standard of performing at least 150 operations per year. These 15 hospitals serve $63 \%(n=3,176)$ of all primary breast cancer patients of the county $(n=5,070)$.

In parallel, continuous progress in adherence to guideline recommendations has been observed in hospital care. As an example serve the results from the national hospital quality report of breast surgery for the performance quality indica- tor 'specimen radiography' (table 3) [23]. Five process quality indicators of the benchmarking from a voluntary network of breast centers [22] are demonstrated (table 4). Marked increases in performance measures were reported for: preoperative histological confirmation of diagnosis (58\% in 2003 to $88 \%$ in 2008) and appropriate endocrine treatment in hormone receptor positive cases (27\% in 2003 to $93 \%$ in 2008). Published data on the impact on survival and improvements in quality of life for patients are expected by the year 2010 .

The systematic pursuit of process improvement by tracking institutional performance quality indicators over time demonstrates the feasibility and practicability of the implementation concept to bridge the gap between determined scientific best evidence and applied best practice in hospital-based care. The cue to action is to make evidence-based qualified multidisciplinary breast health care available to the population [26]. As there are various health care systems within the European Union, national and regional adaptations have to be considered, and harmonization of accreditation systems among scientific societies might speed up this process [25]. 
From the literature, we know that practice variation in breast cancer care has a significant impact alongside the chain of breast health care. Raising the standard of quality assurance for diagnostic breast imaging in the diagnostic setting alone, even without an established mammographic screening program, has demonstrated a remarkable effect with a rise of $14 \%$ of cancer cases detected in the favorable early stage [27]. Breast cancer patients receiving less than definitive care showed a higher recurrence rate and 5-year mortality [28]. Breast surgery performed by a specialist surgeon has an impact on survival and care [29]. Improvement in treatment care and other factors apart from mammographic screening have shown a total effect of $14.9 \%$ reducing mortality in England and Wales 1990-1998 [30]. Patients with early breast cancer without adjuvant systemic treatment had a significantly higher recurrence rate, with a more than $25 \% 10$-year risk of relapse and a corresponding 10-year breast cancer death rate of more than $10 \%$ [31].
Compliance with guidelines for systemic treatment is associated with improved survival in node-negative breast cancer [32]. Furthermore, research has demonstrated that treatment for breast cancer in accordance with clinical practice guidelines and recommendations improves quality of care and reduces inappropriate interventions and unnecessary costs [33-35].

The results of the concert of efforts undertaken by the medical societies to optimize national breast cancer care by organizational centralization of multidisciplinary medical competence in $\mathrm{CBCs}$, aiming to attain continual quality of health care by implementation of evidence- and consensus-based guidelines, is encouraging. However, the proof of concept is still pending until the data of the population-based cancer registries are analyzed for survival estimates.

\section{Conflict of Interest}

None of the authors have any conflict of interest to declare.

\section{References}

1 Robert Koch-Institut (Hrsg.) und die Gesellschaft der epidemiologischen Krebsregister in Deutschland e.V. (Hrsg.): Krebs in Deutschland 2003-2004. Häufigkeiten und Trends, 6. überarbeitete Auflage. Berlin, Druckhaus Berlin-Mitte GmbH, 2008.

2 Ferlay J, Autier P, Boniol M, Heanue M, Colombet M, Boyle P: Estimates of the cancer incidence and mortality in Europe in 2006. Ann Oncol 2007;18: 581-592.

>3 Brenner H, Stegmaier C, Ziegler H: Long-term survival of cancer patients in Germany achieved by the beginning of the third millennium. Ann Oncol 2005;16:986.

4 Gondos A, Bray F, Hakulinen T, Brenner H, and the EUNICE Survival Working Group: Trends in survival in 11 European populations from 1990 to 2009: a model-based analysis. Ann Oncol 2009;20: 564-573.

5 Raab-Schlesinger A, Eckel R, Engel J, Sauer H, Löhrs U, Molls M, Hölzel D: Metastasiertes Mammakarzinom: Keine Lebensverlängerung seit 20 Jahren. Aerzteblatt 2005;102:B2280-B2288.

6 Engel J, Nagel G, Breuer E, Meisner C, Albert US, Strelocke K, Sauer H, Katenkamp D, Mittermayer C, Heidemann E, Schulz KD, Kunath H, Lorenz W, Hölzel D: Primary breast cancer therapy in six regions of Germany. Eur J Cancer 2002;38:578-585.

7 Engel J, Ludwig S, Schubert-Fritschle G, Tretter W, Hölzel D: Cancer prevention and the contribution of cancer registries. J Cancer Res Clin Oncol 2001; 127:331-339.

8 Sachverständigenrat für die Konzertierte Aktion im Gesundheitswesen.: Bedarfsgerechtigkeit und Wirtschaftlichkeit. 2001;Bd. I; Bd. II:11;47-45;96.

9 Council of Europe (Hrsg.): Developing a methodology for drawing up guidelines on best medical practice. Recommendation Rec (2001)13 adopted by the Committee of Ministers of the Council of Europe on 10 October 2001 and explanatory memorandum. Strasbourg Cedex, Council of Europe Publishing, 2002.

10 World Health Organisation (WHO): National Cancer Control Programmes: Policies and Managerial Guidelines, 2nd ed. Geneva, Italy, Health and Development Networks (HDN), 2002.
11 Schulz K, Albert US, und die Mitglieder der Arbeitsgruppe 'Konzertierte Aktion': BrustkrebsFrüherkennung in Deutschland: Stufe 3 Leitlinie Brustkrebs-Früherkennung in Deutschland, ed 1. München, Zuckschwerdt Verlag, 2003.

12 Albert US, Schulz K, the members of the Guideline Steering Committee and the Chairs of the Task Force Groups: Short version of the guideline - Early Detection of Breast Cancer in Germany. An evidence-, consensus- and outcome-based guideline according to the German Association of the Scientific Medical Societies and the German Agency for Quality in Medicine. J Cancer Res Clin Oncol 2004;130:527-536.

13 Kreienberg R, Kopp I, et al.: Interdisziplinäre Stufe-3-Leitlinie für die Diagnostik, Therapie und Nachsorge des Mammakarzinoms. München, Zuckschwerdtverlag, 2004.

14 Lorenz W, Ollenschläger G, Geraedts M, Gerlach F, Gangjour A, Helou A, Kirchner H, Koller M, Lauterbach W, Reinauer H, Sitter H, Thomeczek C: Das Leitlinien-Manual: Entwicklung und Implementierung von Leitlinien in der Medizin. ZaeFQ 2001;95:1-84.

15 Donabedian A: Evaluating quality of medical care. Milbank Memorial Fund Quarterly-Health and Society 1966;44:166-206.

16 Albert US, Schulz KD, Kopp I: Methodik der S3Leitlinien-Aktualisierung am Beispiel der Leitlinie 'Brustkrebs-Früherkennung in Deutschland'. Prävention und Gesundheitsforschung 2008;3:163-172.

17 Albert US, Altland H, Duda V, Engel J, Geraedts M, Heywang-Köbrunner S, Hölzel D, Kalbheim E, Koller M, König K, Kreienberg R, Kühn T, Lebeau A, Nass-Griegoleit I, Schlake W, Schmutzler R, Schreer I, Schulte H, Schulz-Wendtland R, Wagner U, Kopp I: 2008 update of the guideline early detection of breast cancer in Germany. J Cancer Res Clin Oncol 2009;135:339-354.
18 Kreienberg R, Kopp I, Albert US, Bartsch H, Beckmann M, Berg D, Bick U, du Bois A, Budach W, Dunst J, Engel J, Ernst B, Geraedts M, Henscher U, Hölzel D, Jackisch C, König K, Kreipe H, Kühn T, Lebeau A, Leinung S, Link H, Lick H Madjar H, Maiwald A, Maiwald G, Marschner N, Naß-Grigoleit I, Possinger K, Reiter A, Sauerbrei W, Schlake W, Schmutzler R, Schreer I, Schulte H, Schulz K, Souchon R, Thomssen C, Untch M, Wagner U, Weis J, Zemmler T: Interdisziplinäre S3-Leitlinie für die Diagnostik, Therapie und Nachsorge des Mammakarzinoms. München, Zuckschwerdt Verlag, 2008.

19 Albert US, Koller M, Lorenz W, Doherty J, Schulz KD, Wagner U, Kopp I: Implementierung und Evaluation von Leitlinien auf nationaler Ebene: Entwicklung eines Konzeptes für die Stufe-3-Leitlinie Brustkrebs-Früherkennung in Deutschland. ZaeFQ 2004;98:347-359.

20 Perry NM: Quality assurance in the diagnosis of breast disease (EUSOMA Working Party). Europ J Cancer 2001;37:159-172.

21 Groenewegen P, Westert G: Is there a time trend in medical practice variations? J Public Health 2004;12:229-236.

22 Brucker S, Schumacher C, Sohn C, Rezai M, Bamberg M, Wallwiener D, the Steering Committee: Benchmarking the quality of breast cancer care in a nationwide voluntary system: the first five-year results (2003-2007) from Germany as a proof of concept. BMC Cancer 2008;8:358.

23 Veit C, Bauer J, Döbler K, Eckert O, Fischer B, Woldenga C (Hrsg.): Qualität sichtbar machen. BQS-Qualitätsreport 2006. Düsseldorf, Schotte, Krefeld, 2007.

24 Du Bois A, Misselwitz B, Stillger R, Jackisch C, Schwab R, Gnauert K, Hills R, Wagner U: Versorgungsstruktur und Qualität bei der Behandlung des Mammakarzinoms. Eine Untersuchung am Beispiel der Daten aus Hessen 1996-2002. GebFra 2003;63:743-751.

25 Blamey RW, Cataliotti L: EUSOMA accreditation of breast units. Eur J Cancer 2006;42:1331-1337. 
26 Europarat: Recommendation of the committee of ministers to member states on developing a methodology for drawing up guidelines on best medical practice. Rec (2001)13. Entwicklung einer Methodik für die Ausarbeitung von Leitlinien für optimale medizinische Praxis. Empfehlung Rec (2001)13 des Europarats und Erläuterung des Memorandum. Deutsche Ausgabe. Z ärztl Fortbild Qual Gesundh wes 2002;96:1-60.

27 Katalinic A, Bartel C, Raspe H, Schreer I: Beyond mammography screening: quality assurance in breast cancer diagnosis. Br J Cancer 2007;96:157161.

-28 Lash TL, Silliman RA, Guadagnoli E, Mor EV: The effect of less than definitive care on breast carcinoma recurrence and mortality. Cancer 2000;89: 1739-1747.

29 Gillis C, Hole D: Survival outcome of care by spe cialist surgeons in breast cancer: a study of 3,786 patients in west of Scotland. BMJ 1996;312:145148
30 Blanks RG, Moss SM, McGahan CE, Quinn MJ, Babb PJ: Effect of NHS breast screening programme on mortality from breast cancer in England and Wales, 1990-8: comparison of observed with predicted mortality. BMJ 2000;321:665-669.

31 Chia S, Speers C, Bryce J, Hayes M, Olivotto I: Ten-year outcomes in a population-based cohort of node-negative, lymphatic and vascular invasionnegative early breast cancer without adjuvant systemic therapy. J Clin Oncol 2004;22:1630-1637.

32 Herbert-Croteau N, Brisson J, Latreille M, Rivard

M, Abdelaziz N, Martin G: Compliance with consensus recommendations for systemic therapy is associated with improved survival of women with node negative breast cancer. J Clin Oncol 2-82004;22.

33 American Society of Clinical Oncology (ASCO): Outcomes of cancer treatment for technology assessment and cancer treatment guidelines. 1996;14: 671-679). J Clin Oncol 1996;14:671-679.
44 Smith T, Hillner B: Ensuring quality cancer care by the use of clinical practice guidelines. J Clin Oncol 2001;19:2886-2897.

35 Guadagnoli E, Shapiro C, Weeks J, et al.: The quality of care for treatment of early stage breast carcinoma. Cancer 1998;83:302-309.

36 NBCC National Breast Cancer Center: Clinical practice guidelines for the management of early breast cancer, ed iSource. Australia, NBCC National Breast Cancer Center 2001, www.nbcc.org.au.

37 O'Higgins N, Linos DA, Blichert-Toft M, Cataliotti L, de Wol C, Rochard F, Rutgers E, Roberts P, Mattheim W, da Silva MA, Holmberg L, Schulz KD, Smola MG, Mansel RE: European guidelines for quality assurance in the surgical management of mammographically detected lesions; in Perry N, Broeders M, de Wolf C, Toernberg S, Holland R, von Karsa L (eds): European Guidelines for Quality Assurance in Breast Cancer Screening and Diagnosis. Luxembourg, Office for Official Publication of the European Communities, 2006, pp. 315-320. 